Max-Planck-Institut für demografische Forschung

Max Planck Institute for Demographic Research

Konrad-Zuse-Strasse 1 - D-18057 Rostock - GERMANY

Tel +49 (0) 3812081 - 0; Fax +49 (0) 3812081 - 202;

http://www.demogr.mpg.de

MPIDR WORKING PAPER WP 2010-034

DECEMBER 2010

\title{
The reciprocal relationship between \\ the state and union formation across \\ Western Europe: policy dimensions and theoretical considerations
}

Brienna Perelli-Harris (perelli@demogr.mpg.de)

Nora Sánchez Gassen (sanchez@demogr.mpg.de)

This working paper has been approved for release by: Michaela Kreyenfeld (kreyenfeld@demogr.mpg.de), Acting Deputy Head of the Laboratory of Economic and Social Demography.

(C) Copyright is held by the authors.

Working papers of the Max Planck Institute for Demographic Research receive only limited review. Views or opinions expressed in working papers are attributable to the authors and do not necessarily reflect those of the Institute. 
The reciprocal relationship between the state and union formation across Western Europe: policy dimensions and theoretical considerations

Brienna Perelli-Harris and Nora Sánchez Gassen

Max Planck Institute for Demographic Research

We would like to thank Christin Löffler for assisting with the literature review and early ideas about the project. We would also like to thank Wendy Sigle-Rushton, Gunnar Andersson, Gerda Neyer, Sebastian Klüsner, Sandra Krapf, Mikolaj Szoltysek and participants at the European Population Conference and SPaDE workshop in Stockholm for insightful comments and advice on previous drafts. 
Although cohabitation and childbearing within cohabitation has increased dramatically in Europe over the past decades, the variation across Europe remains remarkable. Most studies on changing union formation have not explicitly addressed how state policies may be facilitating cohabitation or, alternatively, stalling the increase of cohabitation by privileging marriage. Indeed, the relationship between policies and union formation is complicated, as states may have passed legislation in response to increasing cohabitation. As a first step to understanding this reciprocal relationship, we provide here an overview of the policies that may impact union formation. Drawing on secondary sources and legal documents, we describe the policy dimensions that regulate the relationship between couples, and between couples and their children. We also discuss theoretical issues and explore examples from across Western Europe. As a whole, this overview raises questions about the changing "institution" of marriage, as well as the increasing "institutionalization" of cohabitation. 
The interaction between public and private spheres has been of central concern to sociologists, political scientists, and demographers (Esping-Andersen 1990, Orloff 1993). A number of broad studies has examined whether and how policies impact family behavior (Hantrais 2004; Hantrais and Letablier 1998, Gauthier 1996, Salles 2006), but demographers have primarily focused on whether family policies can raise fertility, an important issue in countries with very low fertility (Neyer and Andersson 2008, Gauthier 2007, Hoem 2008, McDonald 2006). In general, social scientists have paid far less attention to how family policies and laws shape union formation and union status at birth. Although a large literature describes the laws regulating cohabitation and nonmarital childbearing for individual countries, and some studies have compared the legal consequences of union types across countries (Waaldijk 2005b), this information has not been synthesized to be useful for studying the impact of policies on actual union formation behavior. In this paper, we provide a comprehensive overview of the policies that may impact union formation and discuss general theoretical perspectives on the role of the state on union formation. By examining policy dimensions in detail and exploring examples from across Western Europe, we raise questions about how individuals respond to changing institutional structures, or alternatively how legal structures are modified to reflect changes in societal-level behavior.

The increase in cohabitation and childbearing within cohabitating unions has been one of the most striking changes in the family in the past few decades (Kiernan 2004, Perelli-Harris et al 2010a, Perelli-Harris et al 2010b). Although childbearing within cohabitation has increased in nearly every country in Europe, the variation across countries is remarkable (Kiernan 2004; Perelli-Harris et al. 2010b and see Figure 1). Northern Europe is characterized by a high percent of births within 
cohabitation; for example, in the early 2000s over $40 \%$ of births occurred within cohabitation in Norway and Sweden. Western Europe has had greater variation in the percent of births within cohabitation; with nearly $40 \%$ of all births occurring within cohabitation in France, but only about $20 \%$ of births occurring within cohabitation in the Netherlands and Western Germany. Southern Europe, however, has generally experienced only a small increase in the percent of births within cohabitation; in Italy about 7\% of births occurred within cohabitation. Eastern Europe has also experienced rapid and substantial increases in childbearing within cohabitation (Kostova 2008, Hoem et al 2009, Perelli-Harris and Gerber 2011), but here we only discuss developments across Western Europe.

Most theories explaining the increase in cohabitation and childbearing within cohabitation focus on structural, ideational, or cultural explanations (Perelli-Harris et al 2010a, Lesthaeghe 2010, van de Kaa 2001, Reher 1998). A number of singlecountry, individual-level studies have shown that education (e.g. Blossfeld and Huinink 1991; Thornton et al. 1995), employment (e.g. Liefbroer and Corijn 1999; Oppenheimer 2003), or economic resources (e.g. Bracher and Santow 1998; Xie et al. 2003) influence the type of union formed, but few studies compare these relationships across countries or take into account the impact of policies (for exceptions see LeGoff 2002; Baizan, Aasve, and Billari 2004). Some studies in the U.S. examine the impact of welfare policies on the likelihood of cohabiting or marrying after a birth, but these studies focus on disadvantaged single or cohabiting mothers who are more likely to receive welfare payments (Carlson et al 2004). In general, country-specific policies and legislation are rarely discussed as an explanation for the variation in the levels and timing of cohabitation and childbearing within cohabitation across countries. Thus, although cultural and ideational developments may influence behavior and 
indeed may lead states to reform their policies, here we focus on how the policies and laws themselves may be influencing couples’ decision-making processes and producing variation across countries.

The policies related to union formation are complex and multi-faceted and may be only indirectly related to the phenomenon. Unlike in the United States, where former president George W. Bush’s administration implemented the "Healthy Marriage Initiative” to explicitly encourage marriage, most governments in Europe have not directly attempted to increase marriage or influence the rate of childbearing within cohabitation (Cherlin 2009). In fact, many countries have responded to behavioral change by enacting legislation that reflects new demographic realities, such as expanding cohabitors' rights or instituting registration systems to record civil unions. Therefore, it is important to explore both the potential impact of policies on cohabitation and marriage, and how the state adopts legislation and policies to changes in behavior. This paper is a first step to better understand the range of policy dimensions that may be related to union formation, a step important for determining causality in either direction.

Taken as a whole, our goal in this paper is to raise theoretical issues relevant to any analysis of the relationship between the state and union formation, and to provide a framework for the policy dimensions that may be related to cohabitation and marriage, especially with respect to childbearing. Drawing on secondary sources, legal documents (usually in the original language), and official websites, we systematically describe the policy dimensions that regulate the relationship between couples, and between couples and their children. Throughout the paper, we interweave examples from around Western Europe to highlight how policies can encourage or discourage the increase of childbearing within cohabitation; however, 
we do not attempt to classify countries here. Also, we do not aim to imply causality. Instead, the paper aims to raise awareness of the potential impact of policies on family formation and assist in the interpretation of empirical findings. And fundamentally, the paper serves as a call for empirical research into the effects of social policies on union formation behavior.

\section{THEORETICAL CONSIDERATIONS}

A rich body of social research has raised important theoretical considerations that must be addressed when analyzing the relationship between the state and the family. Here we follow the theoretical framework proposed by Neyer and Andersson (2008) to raise issues pertinent to cohabitation and childbearing within cohabitation. Neyer and Andersson describe three major conceptualizations of family policies: (1) Kamerman and Kahn’s (1991) approach to family policies that includes “everything that government does to and for the family...” ; (2) the approach of feminist welfarestate researchers, who regard family policies as a central part of the welfare-state context and define family policies as policies that structure society by structuring private relationships (e.g. partnership and parenthood); and (3) Bordieu’s (1996) argument that the state uses family policies to construct and institutionalize a particular form of family. Like Neyer and Andersson (2008), we draw on these three conceptualizations of family policy to explore 1) the "quantity,” “coherence,” and “timing” of family policies related to childbearing within cohabitation; 2) how family policies are situated in welfare-states contexts and influenced by other legal, cultural, gender, and economic institutions, and 3) the potential disconnect between laws, family ideologies, perceptions, and behavior.

\section{The quantity, coherence, and timing of policies}


Drawing on the work of Kamerman and Kahn, Neyer and Andersson (2008) describe how a broad spectrum of family policies may be more effective at influencing behavior than stand-alone policies (quantity), how family policies need to fit together to achieve similar goals (coherence), and how the timing of policies needs to precede societal development rather than lagging behind it (timing). Each of these dimensions may also be important for how policies shape individuals’ decisions about cohabitation and marriage. First, the sheer quantity of incentives supporting either marriage or cohabitation could deter or facilitate the spread of cohabitation, for example the number of legislative acts passed on tax benefits, laws of inheritance, protection of private property, or the provision of equal parental rights. Second, individual policies or laws may be ineffective if they conflict with other policies. States may aim to support cohabitation by providing cohabitors with the same tax and welfare benefits granted to married people, but those benefits may be irrelevant in the long run if, for example, cohabitors only have limited rights to inherit from each other, as in Sweden ([Agell and Brattström 2008] in Ohlsson 2009; Ryrstedt 2005b). Thus, it is important to evaluate the coherence of policies across different policy domains as well as the relative importance of the policies (Neyer and Andersson 2008).

Understanding the timing of the enactment of policies and legislation is also fundamental to understanding whether policies are leading to changes in behavior or reacting to changes that have already occurred. Only by knowing that a change in policy occurred before a change in behavior can we conclude that the policy may have led to the new behavior, although policies enacted at a later time may indeed facilitate an increase in behavior. For example, the initiation of marital benefits led to a sharp increase in marriage in several countries. In Sweden, marriage rates spiked in late 
1989, because many couples wanted to be eligible for the National Widow's Pension Scheme that required couples be married before 1990 (Hoem 1991). In Austria, the introduction and elimination of allowances restricted to married people led to marriage booms in 1972, 1983, and 1987 and could have stalled increases in nonmarital childbearing directly afterwards (Prioux 1993; Prskawetz et al. 2008). On the other hand, the introduction of single-mother benefits could have led to an increase in births in cohabitation in several countries. The French government initiated a single-mother benefit (allocation pour parent isolé) in 1976 to provide a monthly income to single mothers for up to three years after each birth. Some have argued that this means-tested benefit may have led low-income cohabiting couples to hide their relationships and postpone marriage, resulting in an increase in births within cohabitation throughout the 1980s, especially among the least educated (Knijn et al 2007). Nonetheless, such examples must be used with caution: even if the implementation of a policy may seem to have led to an increase in behavior, the relationship between a policy and behavior may in fact be spurious and instead caused by other factors such as social or economic change.

\section{Situating policies related to cohabitation and childbearing within cohabitation}

When evaluating the relationship between policies and behavior, it is very important to remember that policies, and indeed individuals, are located within specific historical, culture and political contexts. A state’s orientation and ideology clearly dates back to cultural and historical factors that determine the state's relationship to families and the individual (Bradley 2001). Indeed, family systems that may have shaped marriage and cohabitation patterns in the past (Szoltysek 2010) can continue to influence both family patterns and policies today. For example, in certain countries, constitutions or civil codes explicitly refer to marriage as one of the 
fundamental ways in which society is organized. In Germany, "marriage and family are under the special protection of the state” (German Basic Constitutional Law 1949; Ostner 2001). In other countries, such as Sweden, socialist ideology may have encouraged the legal acceptance of other family forms, thus leading to a legislation of neutrality that favors neither marriage nor cohabitation (Bradley 2001). In addition, the fundamental structure of the legal system itself may be essential to a state's ability to respond to changes in the family or regulate cohabitation. Bradley (2001) argues that "Differences in legal tradition are (another) ... factor which may explain divergent approaches to statutory regulation of cohabitation.” Thus, the agility and type of courts and legislative bodies (e.g. common law vs. civil law) may impede or facilitate the development of family law.

Welfare-state researchers emphasize that family policies and laws are situated within state contexts that structure society (Esping-Andersen 1990). The welfare-state context may be critical to how states relate to individuals and families. States often protect and provide for their constituents by implementing tax and transfer systems; whether these systems are organized around married couples or individuals could be crucial to whether couples find it more advantageous to marry or remain within cohabitation. Several classification systems have specified how nations cluster in types of welfare states, the most common of which is Esping-Andersen's “three worlds of welfare capitalism” (Esping-Andersen 1990). The welfare-state classification system may be useful for organizing the relationship between policies and childbearing within cohabitation, because it provides a general depiction of how the state regards and financially supports families and individuals.

On the other hand, welfare-state classification systems may be completely orthogonal or even irrelevant to cohabitation and childbearing within cohabitation. 
The welfare-state typology often ignores other types of legal, cultural, gender, and economic institutions that may not be directly related to family policy, but nonetheless have a strong effect on individual behavior (Neyer and Andersson 2008). Feminist welfare-state researchers have emphasized how gender needs to be incorporated into such classification schemes in order to accurately capture the gender hierarchies and power relations within families (Orloff 1993). Such considerations are of particular importance to union formation, since state policies may favor a particular type of gender ideology that may then structure its regulation of formal and informal relationships. For example, Scandinavian countries have been motivated to increase gender equality at home or in the workforce and create policies that support women's position within cohabitation. In addition, Scandinavian policies that support gender equality may also have led women to become more economically independent and therefore less reliant on the legal institution of marriage. The German state, on the other hand, has favored the breadwinner model and essentialized women's role towards the household and raising children. This orientation towards conservative gender roles has been essential for structuring tax and benefits around marriage. Thus, in order to understand how the state may influence union formation behavior, it is essential to recognize the general influence of political and ideological contexts.

Like many other family policy researchers, we tend to focus on the national level, but policies at different geographic levels may also be of relevance to the increase in cohabitation. Policies in European countries may be subject to or highly influenced by supra-national institutions, such as the European Union or Council of Europe. For example, twenty-two states of the Council of Europe have ratified the 'European Convention on the Legal Status of Children born out of Wedlock' of 1975, thereby obliging themselves to revise their national law to "bring the legal status of 
children born out of wedlock into line with that of children born in wedlock” (Council of Europe 1975). Even when there is no obligation to adapt national legislation to European norms, governments may do so to garner political favor or raise their esteem. National family law has also been the subject of international courts; for example, in December 2009, the European Court of Human Rights declared that current German law, which does not allow unmarried fathers to go to court over custody issues, discriminates against fathers and does not comply with the European Convention on Human Rights. In August 2010, the German Federal Constitutional Court agreed and declared the current legal situation to be unconstitutional (Sueddeutsche Zeitung 2009). This example shows how federal policies are constantly shifting, not only due to internal demands but also external pressures. Finally, within countries, policies may also vary by local or regional areas. For example, different regions of Spain have enacted their own policies regarding cohabitation, and some regions have even created systems for registering cohabitation (González Beilfuss 2005). In fact, studying regional variation in policies may provide the analytical power needed to determine the impact of policies on behavior (Neyer and Andersson 2008).

Besides variation across regions, childbearing within cohabitation may differ substantially within nations by educational, class, ethnic and religious groups, due to the differential impact of policies. For example, women with low education and few employment prospects may be more likely to marry if they gain greater tax advantages than highly educated women who have similar incomes as their spouses, as in Germany (Konietzka and Kreyenfeld 2002). Immigrants or cross-national couples may marry in order to attain residence permits or citizenship. In addition, policies may only become relevant at different periods throughout the lifecourse. As 
discussed in Perelli-Harris et al (2010b), individuals may decide to marry at various points during the childbearing process, when policies provide certain benefits to married fathers. For instance, couples in Switzerland may be more likely to marry after conception to gain full access to parental rights, while couples in Sweden may only marry after buying a house or near the end of life when inheritance becomes more important.

Finally, legal regulations may interact with cultural, historical, and economic institutions to produce substantial variation across regions, even within the same country. For example, the East and West regions of Germany have been governed by the same legal regulations for 20 years, but the level of nonmarital childbearing is strikingly different (Konietzka and Kreyenfeld 2002): in the West, 26\% of all births occurred outside marriage in 2009, while in the East nearly 58\% occurred outside of marriage (Statistisches Bundesamt 2010). Researchers have explained these differences with a number of economic, social, and historical factors. First, Eastern German women have had a long history of attachment to the labor force, while Western German women have been more likely to rely on their husbands for financial support (Konietzka and Kreyenfeld 2002). The labor force attachment in the East may have led to female independence and a preference for cohabiting unions, which are easier to dissolve. Second, the current Eastern German level of nonmarital childbearing may date back to attitudes formed in the 1980s, when the social policies of the German Democratic Republic stipulated that only unmarried women qualified for maternity leave (Salles 2006). Although the policies have changed since, attitudes formed during this period may persist. Or even more dramatically, the differences in nonmarital childbearing between East and West Germany may be due to policies set in motion during the Prussian regime (Goldstein and Kluesener 2009). Thus, the 
German example shows that although current policies may play a very important role in encouraging or discouraging a particular behavior, they may be insufficient to alter underlying cultural patterns.

\section{Constructing the family}

Although the state may try to structure families and individuals, family policies and laws may not correspond to social realities or the changing nature of relationships (Bourdieu 1996). In other words, family policies and laws may not reflect what families "should be like" according to societal norms and values. This disconnect with social reality is particularly pertinent with respect to cohabitation, which is outside of official legal marriage and may not be regulated by the state. In fact, couples may live together without marrying specifically to avoid the legal constraints of marriage and the fallout after a divorce. Thus, in some countries, or for certain policy dimensions, cohabitation and childbearing within cohabitation may be completely outside of legal jurisdiction.

Even if family policies and laws exist to regulate and support particular family forms, individuals may not be aware of them, or may ignore them, even though the laws and policies may be in their best interest. Cohabiting couples with children may know they should take the necessary steps to attain legal recognition for the father, but fail to do so, a failure which could have negative consequences in case of union dissolution or death (Schrama 2008). Likewise, marriage may be in a couple’s best financial interest, but the couple may still fail to marry because they are ignorant of the benefits or beset by inertia. Alternatively, individuals may have the perception that they maintain certain rights when they do not. For example, in the UK, there is a pervasive myth that people in so-called “common law marriages” (cohabiting unions) enjoy similar rights to inheritance after their spouses' death as people in legal 
marriages, even though they do not. Evidently this myth is widespread; a UK survey showed that more than half of cohabiting respondents believed they have the same rights as married people (Barlow et al 2005). These examples provide evidence that: "Family policies always act on two levels: on the level of facts and on the level of perception.” (Neyer and Andersson 2008). The absence or presence of a body of law that regulates cohabitation may not impact cohabitation rates at all.

Another important point is that policy-makers may be motivated to enact laws or policies that have nothing to do with heterosexual cohabitation, but instead arose from the struggle for same-sex couples to receive the same rights and protections as heterosexual married couples. The creation of registered partnerships to protect samesex couples may have led to the rise of legal registration for heterosexual couples. Both the Netherlands and France implemented registered cohabitation for heterosexuals in order to grant same-sex couples legal rights, and yet the debates surrounding their implementation were quite distinct and resulted in different outcomes for heterosexual couples. Debates in France danced around reproductive rights, such as access to adoption and reproductive technologies, especially for samesex couples; in the end, Pacs provided no rights for joint adoption or medically assisted insemination (Borrillo and Fassin 2004). In the Netherlands, however, parenthood for same-sex couples was not as central an issue, resulting in similar rights as married couples, for both same-sex and straight couples.

Finally, policies aimed at protecting individuals may have consequences that were unintended by policy-makers. A number of countries have enacted a system of transfers and benefits as part of a social safety net to protect vulnerable people, namely single mothers and their children. Family policies and legal regulations that were originally designed for these purposes may lead to unintended or even unwanted 
outcomes. For example, cohabiting couples may try to profit from single mother benefits by postponing entry into marriage and hiding cohabiting relationships (Hantrais 2004; Noack 2001; Martin and Théry 2001). The French single-mother benefit mentioned above could be said to have had unintended consequences, since it was most likely not the government's intent to increase childbearing within cohabitation. The Netherlands also provided unemployment benefits to single mothers with children under the age of 18 , and the rising numbers of mothers on benefits led to concerns about cohabitation fraud (Knijn et al 2007). Recently, governments have attempted to reduce this behavior by putting a strong emphasis on the distinction between single and cohabiting parents and eliminating incentives not to enter marriage (see, for instance, Noack 2001 for the Norwegian case, or Hantrais 2004 for the UK). Taken together, these examples show how state policies do not necessarily produce the intended outcomes, nor correspond to individual-level behavior.

These examples demonstrate that social scientists who seek to analyze the interrelationship between policies and behaviors must keep in mind the entire set of policies that could influence behaviors. Researchers need to remember that policies and individuals are situated within historical, cultural, and political settings, and that polices and laws do not necessarily reflect or influence the behaviors and practices of the population. Nonetheless, even if the relationship between policies and behavior is not straightforward, policies are still likely to be an important factor explaining the variation in cohabitation and childbearing within cohabitation across countries. Couples may make decisions to marry or remain within cohabitation precisely because there are laws that encourage them to do so. Therefore, we now turn to a discussion of the specific ways that the state is involved in regulating private 
relationships and outline which policy areas we consider to be most relevant for cohabitors and their children.

\section{REGULATING RELATIONSHIPS}

The state has an interest in regulating two types of relationships that are relevant to union formation: the relationship between couples and the relationship between parents and their children. Both types of relationships may impact decisions to remain within cohabitation or marry, and we discuss them separately. With respect to couples, we are primarily interested in how the state regulates intimate, long-term co-residential partnerships, or those that appear to be more similar to marriage. In some countries, cohabiting unions tend to be shorter in duration and closer to an “alternative to single” (Heuveline and Timberlake 2004), but fewer regulations govern such relationships. Indeed, the duration of the relationship often determines the degree to which the relationship is regulated: in some countries regulations do not go into effect until the couple can prove that they have lived together for a specific period of time (often two years).

Historically in Europe, the state has had an interest in governing the relationship between couples in order to formalize the affiliation between nonbiologically related individuals, regulate property and inheritance, provide protection to individuals, manage disputes between citizens, and structure the taxation of households (Coontz 2005). The state (as well as the church) regulated relationships between couples through official marriage, and unmarried couples were outside of legal jurisdiction. Nonetheless, some couples did live outside of marriage, usually due to social or financial barriers (Ehmer 2002). Thus, cohabiting couples, with the exception of some avant garde couples who protested the institution of marriage (Trost 1978), were by and large disadvantaged, i.e. rural inhabitants, previously 
married, or the poor (Kiernan 2004; Mitterauer 1983; Laslett et al 1980). Indeed, in some countries, marriage was seen as such a central institution that living together outside of wedlock was considered criminal. In these countries, laws that allowed a man and woman to live together without being married were updated only in the mid $20^{\text {th }}$ century: as late as 1968 in Italy, 1970 in parts of Germany, and 1972 in Norway (Bradley 2001), although clearly most of the laws were not upheld.

Starting in the late 1960s and early 1970s, the institution of marriage began to fundamentally change throughout Europe and more couples began to live together outside of marriage. During this period, values and attitudes about sex, gender relations, women's employment, and the role of the individual and society changed dramatically (Lesthaeghe 2010; van de Kaa 2001). Simultaneously, states began to provide greater welfare protection of the weak and vulnerable and increased state support for families, leading to diverging trajectories of welfare and family policy contexts (Knijn et al 2007, Gauthier 1996). These forces resulted in fundamentally different national and state approaches to the institution of marriage and cohabitation, and the policies aimed at regulating the relationship between unmarried partners continue to evolve today.

Theoretically, the laws and regulations governing marriage and cohabitation range along a spectrum, with legal systems that equalize the rights of cohabitors and married people at one end and legal systems that ignore cohabitation or actively favor marital unions at the other. Thus, the two ends of the spectrum range from equalizing cohabitation with marriage to privileging marriage. As discussed above, however, the laws and policies of a particular country are not always coherent and oriented towards achieving the same goal. Therefore, it can be difficult to neatly place countries along 
this spectrum or apply ideal types without an in-depth analysis of policy dimensions, which we outline below.

\section{Registered unions}

Before describing the policy dimensions, it is important to note that several countries e.g. the Netherlands, France, Luxembourg, Belgium, and even some regions of Spain and Italy - have enacted registered partnerships to provide some of the protections and obligations of marriage but not all. These registered unions are open to homosexual couples, and in Belgium even close relatives who live together can register their partnerships (De Schutter and Waaldijk 2005). Countries with registered cohabitation fall between the two extremes of the spectrum; governments recognize that cohabiting unions exist and should be regulated by law, but they have not simply granted all cohabitors equal rights to married people. In addition, in countries with registered cohabitation, a substantial proportion of cohabitors do not register their unions and continue to fall outside of the law or only have limited rights. Thus, multiple types of unions could exist in these countries; for example, Poortman (2010) has identified five types of unions in the Netherlands: marriage (including marriage with prenuptial agreements), registered cohabitation, non-registered cohabitation, and even cohabitating unions with a private legal contract that provide some inheritance rights and/or provisions for alimony.

Indeed, the Netherlands represents a country that has attempted to recognize cohabitation by creating an extra legal category, but has not necessarily achieved the goal of incorporating cohabitation into a legal framework (Schrama 2008). The rights and responsibilities accorded to registered partnerships are very similar to marriage, with only a few exceptions related to the ease of dissolution and parental rights (Antokolskaia and Boele-Woelki 2002). Registered cohabiting partners have similar 
rights to financial provisions, maintenance, and alimony, and since 2002 automatic joint custody of children born into the union. Registration of cohabiting unions takes place in front of a registrar, who is allowed - but not required - to execute the same ceremony as for marriage (Boele-Woelki and Schrama 2005). The dissolution of registered partnerships, however, is much easier than divorce: although it is a formal process, cohabitors can apply jointly and unilaterally for dissolution, without court intervention (Antokolskaia and Boele-Woelki 2002).

Although the Dutch government has aimed to recognize cohabiting unions by adopting registered partnerships, this goal has not necessarily been achieved and may even have led to unintended consequences. The Dutch government enacted the Act on Registered Partnerships in 1998 to acknowledge the social and economic importance of cohabiting relationships and to provide legal recognition for same-sex couples. However, because marriage became an option for same-sex couples in 2001, the reason to for same-sex couples to register their partnerships generally disappeared (Anatolskaia ad Boele-Woelki 2002). Nonetheless, registered partnerships remained in effect, even increasing substantially in 2001. This increase may have been because the act provided a means for cohabiting partners to reject the formal institution of marriage or to attain joint custody over children. However, the act also allowed married couples to convert their marriages into registered partnerships, facilitating an easier divorce without court intervention. More than half of all registered partnerships initiated in 2003 were former marriages (Boele-Woelki and Schrama 2005).

Therefore, married couples who wanted to divorce may have contributed more to the rise in registered partnerships than cohabiting couples who registered their partnerships for other reasons. Finally, even after the enactment of registered partnerships, only half of cohabiting couples registered their partnerships (or had a 
cohabitation contract) (Poortman 2010). These data indicate that cohabiting couples may be ignorant of the benefits of registering their partnerships, both for themselves and their children, or they may not register their partnerships due to inertia (Schrama 2008). This Dutch example shows that even though a country may implement a system for registering cohabitation, a significant percent of families can remain outside of the law and without all of the protection accorded to families recognized by the law, especially in case of relationship termination.

In France, registered cohabitation was clearly a by-product of the initiative to provide same-sex couples legal status. The French government was disinclined to acknowledge same-sex marriage, and only after many discussions and rearrangements instituted Pacs (Pacte Civil de Solidarite) in 1999 (Martin and Théry 2001). The Pacs does not offer as many benefits as Dutch registered partnerships, but also does not require the same obligations after union dissolution. After registering a Pacs, couples are ensured a number of tax and social security system benefits (e.g. health insurance, maternity benefits, funeral benefits), but must also provide mutual material assistance and become liable for household debt. In case of dissolution, registered cohabiters are not eligible for any compensation or survivors pensions, and they retain possession of their personal property, with joint possession in rare cases (Köppen 2009; Godard 2007; Ferrand 2005; Le Goff 2002; Bradley 2001; Martin and Théry 2001). All in all, the French government continues to emphasize the difference between marriage and Pacs by considering marriage as the superior institution (Bradley 2001, Borrillo and Fassin 2004).

Spain is another interesting example, because the legal situation depends on region rather than federal law. A ruling of the constitutional court in 1994 prompted certain regions to agitate for regulation: the court decided that a woman who had 
cohabited for 55 years was not entitled to receive a widow's pension after her partner's death, even though the couple had opposed marriage for ideological reasons. In response, some regions instituted systems for registering partnerships, while others maintained a more conservative stance (González Beilfuss 2005). Other regional laws, however, do not contain such provisions, because they lack the jurisdiction to legislate in these areas (e.g. the regions of Andalucía, Valencia, Madrid). Finally, some regions in Spain have not enacted laws on cohabitation and common Spanish law applies.

The examples of France, the Netherlands, and Spain show that while governments may have made gains in providing cohabitors with legal recognition through registered partnerships, they nonetheless do not cover the majority of couples living in informal unions - those who remain outside of the law - or provide coherent laws to protect all citizens. These examples show that governments may be willing to provide alternatives to marriage by instituting different types of unions, but that 1 ) the type of registered cohabitation itself still ranges along a spectrum from being very similar to marriage to a less permanent union with fewer rights, and 2) not all cohabiting couples wish to enter into these types of arrangements. Therefore, it is not clear whether provisions for registered cohabitation have led to an increase in cohabitation within any given country, although instituting registered cohabitation was clearly a response to changes in union formation (and rights for homosexual couples, as mentioned above).

\section{Policy dimensions}

We now turn to outlining the specific rights and responsibilities accorded to married and cohabiting couples. Although we aim to be comprehensive, we do not cover some aspects, for example spousal immunity and privilege in court, or compensation in case of wrongful death; we assume that cohabiting couples are unlikely to plan for these 
rare events or consider them when deciding whether to marry. Thus, we focus on the major policies and laws that are most likely to influence a change from cohabitation to marriage. We distinguish between aspects that may be influential during a union, upon union breakdown, and after the death of a partner.

\section{Rights and responsibilities during the union}

Certain laws and policies may result in legal consequences during the partnership. We discuss the following: tax systems, social security (welfare, health insurance), financial maintenance, and the right to adopt and use artificial insemination.

Income tax systems. Income tax policies may be one of the most influential types of policies motivating couples to marry. Like cohabitation policies in general, income tax systems appear to range along a spectrum with individualized taxation that tends to be neutral towards cohabitation at one end, and joint taxation that favors marriage at the other (Dingeldey 2001). In individualized tax systems, taxes are declared separately for each individual, irrespective of whether the person is married or cohabiting. The Scandinavian countries, the UK and Austria belong to this type of system, which in principle does not favor married people over unmarried people. These tax systems might, however, provide family tax instruments that allow for deductions in the case of dependent spouses or children (O’Donoghue and Sutherland 1998).

In joint taxation systems, the income of spouses or all household members is added and then split by a predefined quotient. Joint taxation is mandatory in some states, such as France, but optional in others, such as Germany or Spain. Usually this type of system preferences marriage and might motivate cohabiting couples to marry. In Germany, for example, only married couples can take advantage of tax splitting. This approach is especially advantageous for couples in which one spouse's income is 
higher than the other's (Martiny 2005:94). In France, joint income taxes are calculated by adding the income of all household members and dividing it based on number of household members, with greater quotients for higher-parity children. Married and Pacs couples can take advantage of the tax splitting system, but unregistered cohabiting couples can not (Köppen 2009). However, French cohabiting couples are allowed to include children on one partner's individual declaration and divide the total according to the same schedule as for married couples. Single parents with co-resident children, on the other hand, are able to divide their income by a slightly higher quotient. Until 1996, cohabiting couples in France were able to benefit from the tax advantages granted to single people (Ferrand 2005), which may have provided an incentive for couples to remain unmarried and facilitated the increase in childbearing within cohabitation throughout the 1980s.

Social benefits. In general, states tend to use marital status to restrict access to benefits, but ignore marital status to avoid paying out benefits. For example, in most countries of Europe, health insurance is usually organized around the individual, but partners may cover an unemployed spouse. Some countries require that couples be married; for example in Germany, only married spouses can be co-insured in the public health insurance of the main earner of the household (Martiny 2005). Other countries - such as the Netherlands, France and Austria -- extend public health insurance coverage to unmarried partners, but only under certain conditions (Waaldijk 2005a, Ferrand 2005, Austrian General National Insurance Act). In countries which have introduced a universal right to health insurance, such as Sweden, rights to health care are independent of marital status (Ytterberg and Waaldijk 2005).

The situation for welfare payments, however, is different: states usually focus on de facto residence, not type of union, in order to ensure that payments are not 
provided to households where one member can support the others. This is the situation in all of the 15 pre-2004 member states of the European Union (Hantrais 2004). Nonetheless, cohabitors may be able to hide their relationship in order to receive welfare or unemployment benefits, which has been suggested for eastern Germany (Konietzka and Kreyenfeld 2002).

Financial maintenance: Most European countries, such as England, Norway, Germany, and Switzerland, do not require cohabiting couples to financially support their partners during the relationship (Barlow et al 2005; Noack 2001; Martiny 2005; Becker 1994). In the Netherlands and France, however, registered partners have the same obligation to provide for each other as married couples, while unregistered couples do not; this could be one of the reasons why couples are reluctant to enter into a registered partnership (Boele-Woelki and Schrama 2005; Ferrand 2005). In Spain, the legal situation varies by region; in Catalonia, for example, cohabitors must financially provide for each other during the relationship (González Beilfuss 2005).

\section{The right to adopt and use assisted reproductive technology. In some Western}

European countries, controversy has arisen over whether cohabiting couples, particularly same-sex couples in registered partnerships, should receive assistance in becoming parents (Cherlin 2009). Not all countries allow cohabiting couples the same access to reproductive technology as married couples, although it seems to be easier for cohabiting couples to undergo fertility treatments than adopt a child. In Germany, for instance, the German Civil Code states that only married couples can jointly adopt a child; unmarried people must adopt a child individually. The Medical Association, however, advocates that partners living in stable, long-term relationships should be eligible to use medically assisted methods of reproduction (Bundesärztekammer 2006). Nonetheless, health insurance providers are not legally obliged to co-finance 
treatments if the partners are not married, resulting in a small number of cohabiting couples who can afford such treatments. The situation is similar in Norway, Sweden, Austria and France, where cohabiting couples are allowed to undergo artificial insemination but not adopt jointly (Ferrand 2005; Ryrstedt 2005a and 2005b, Austrian Civil Code, §179). Even couples in French Pacs are not allowed to adopt. In England, and the Netherlands, however, cohabiting couples are allowed to adopt, provided that certain conditions are fulfilled (Boele-Woelki and Schrama 2005; Barlow et al 2005). Interestingly, in Spain, which supposedly follows a traditional family model (Reher 1998), artificial insemination became possible for all women irrespective of marital status in 1988, and couples in stable relationships were allowed to adopt jointly in 1987 (González Beilfuss 2005). Thus, Spain represents a case in which the state’s approach to cohabitation, at least for some policy dimensions, appears to precede the adoption of cohabitation by the general population.

\section{Rights and responsibilities after a union dissolves}

Although few people plan to end a relationship when they enter into it, the policies regulating dissolution and divorce may still be very influential in the choice to cohabit or marry. Some partners may decide to marry to protect themselves in case of union dissolution, particularly after the birth of a child or taking time off of work to maintain the household. On the other hand, the lack of regulation for ending a cohabiting union may be one of the main reasons individuals remain in cohabitation: they do not want to go through a time-intensive and perhaps costly bureaucratic procedure if their union ends. Prior personal experience or watching someone they know (especially parents) may lead them to choose cohabitation over marriage (Thornton 1991). The specific measures of divorce legislation, such as provisions for no-fault divorce, waiting time, division of joint property, and the requirement to pay 
alimony may play a role in dissuading couples to marry. Here, however, we do not focus on differences in divorce law across countries, but instead highlight the potential differences between marriage and cohabitation after a union dissolves. We provide an overview of what we consider to be the most influential aspects: alimony and division of property and household goods.

Alimony: In most European countries, unregistered cohabitors are not obliged to pay alimony to their partner after separation (Barlow et al 2005; Noack 2001; Wellenhofer 2005). Exceptions exist if a couple has common children, in which case many European countries require that the primary childcare provider receives financial maintenance for a limited period (Kulms 1994; Becker 1994). Courts may also provide exceptions to the law, for example in Norway (Ryrstedt 2005a) Germany (Wellenhofer 2005), and Spain (González Beilfuss 2005). Despite these exceptions, however, the general principle is that former unregistered cohabitors do not have a right to claim compensation. Regarding registered cohabitors, only the Netherlands has enacted legal rules requiring alimony after union dissolution (Boele-Woelki and Schrama 2005). In France, no such obligation exists for Pacs (Ferrand 2005). In Spain, some of the regional laws on registered cohabitation contain provisions for alimony (González Beilfuss 2005).

The division of property and household goods. One of the primary reasons for official marriage has been the legal regulation of property; thus, divorce law is usually well specified in European legal systems and managed through court proceedings. However, because cohabiting couples fall outside the law, far fewer regulations and court proceedings determine the division of property after cohabiting unions dissolve. In many European states, for example Germany, England, and Austria, no laws exist to explicitly deal with the division of property in case of union dissolution, and 
ownership is strictly determined by who paid for the property, with disputes decided in courts (Barlow et al 2005; Wellenhofer 2005). Some European states, however, have implemented laws to regulate the division of property after the breakup of a household. In Sweden, long-term cohabiting partners must equally divide joint property and household goods unless otherwise agreed (Ryrstedt 2005b). Norway allows both partners to claim access to the joint home and part of the household goods; however, cohabiting couples must have lived together for two years or have a child together. Nonetheless, cohabitors are generally treated like single people, with these exceptions only granted on a case-by-case basis (Ryrstedt 2005a). In countries with registered partnerships, partners may be subject to regulations for the division of joint property; for example, in the Netherlands, all goods are considered joint property (Boele-Woelki and Schrama 2005). When Pacs were originally enacted in France, household goods bought during the Pacs would be held jointly (if the Pacsés did not decide differently), but in 2006, each Pacs partner became the sole owner of the goods he/she bought, although partners can decide to hold joint property in a partnership agreement (Godard 2007; Ferrand 2005).

\section{After the death of a partner}

Regulations may also differ for cohabiting and marital partners after the death of a partner. Although most young couples usually do not expect to die in the near future, the security of a legally protected relationship might prompt some couples to marry, especially when children or housing are involved. Here we consider the right to remain in rented housing, inheritance, and receive the deceased spouse's pension.

The right to remain in housing rented by a deceased partner. Across Europe, governments have extended the right to rent a deceased partner's housing, although the exact conditions differ by country. For example, in France, surviving cohabitors 
have the right to stay in the common home if the deceased partner was the sole tenant of the apartment and the surviving partner had lived there for at least one year (French Law no. 89-462 of 6. July 1989, §14), but partners in Pacs do not need to meet the one year residence requirement (French Civil Code, §763 and §515-6). In Spain, surviving spouses are required to have lived with their partner for two years or have common children. In general, however, states have provided measures to protect surviving partners, regardless of union status, from immediate eviction.

Entitlement to inheritance. If a married spouse dies, the surviving spouse is automatically entitled to inherit property, even without a will. In most European countries, however, such as Austria, France and Germany, cohabitors do not have automatic rights to inherit (Conseil des Notariats de l’Union Européenne 2010). In France, even registered partners are not defined as statutory heirs (Ferrand 2005). Other European countries have started to extend inheritance rights to cohabitors: cohabitors with joint children have limited rights to inherit from each other in Norway (Agency for Public Management and eGovernment (Difi)), England (Barlow et al. 2005), Sweden (Ryrstedt 2005b), and some regions in Spain (González Beilfuss 2005). Nonetheless, cohabitors often have to pay higher inheritance taxes than spouses or family members (e.g. in Germany: Bundesministerium der Justiz 2009). Exceptions to this rule are Austria and Sweden, where inheritance tax has been abolished (Conseil des Notariats de l’Union Européenne 2010; Ryrstedt 2005b), and France, where since 2007 Pacsés, like spouses, do not have to pay inheritance tax (Conseil des Notariats de l’Union Européenne 2010).

The lack of inheritance in many countries leaves cohabitors in a vulnerable position if the deceased was the sole owner of the home; the surviving partner might not have the right to continue to live there. If both cohabitors were owners of the 
home, the surviving partner has more rights to the property, but still might have to pay out the other legal heirs. This insecure legal situation may prompt some couples to marry when they acquire a joint home, as has been suggested in recent research on Sweden (Holland 2010). In some European states such as Austria or France, legal instruments allow cohabitors to acquire the full ownership of joint property if one partner dies (Ferrand 2005). In these countries, the incentives to marry because of joint property acquisition may be less pronounced.

\section{Survivor's Pension}

Cohabitors also have no right to receive a survivor's pension under state pension schemes in Switzerland (Freiburghaus-Arquint 2000), Germany (Martiny 2005), Austria (Mairhuber 2003), England (Barlow et al. 2005) and France - not even Pacspartners are considered for survivor's pensions (Ferrand 2005). The situation is different only in Sweden and Norway, where cohabitors can profit from a survivor's pension if they have children together, or in Sweden if they have been in a long-term relationship (Noack 2001; Ministry of Health and Social Affairs and National Social Insurance Board 2007). Thus, overall, cohabitors are in a disadvantaged position in case of a partner's death.

Our overview of the policy dimensions that regulates couples leads us to several conclusions. First, most states have not attempted to create a coherent body of policies for regulating cohabiting partnerships; instead the policies seem to be a patchwork of legal regulations that govern some domains but not others (Australia, which has changed every law to incorporate cohabitation, is an interesting exception, but Australia is outside of our focus on Western Europe). States with registered partnerships have systematically defined the rights and obligations for registered partners, but nonetheless, the majority of cohabitors in these countries continue to 
remain outside of registered partnerships and thus outside of the law. Experts often point out that non-registered cohabitors can close legal gaps by entering into partnership contracts (e.g. Boele-Woelki and Schrama 2005), but only few couples negotiate such contracts (e.g. Germany: see Martiny 2005). Of course, couples may cohabit to avoid the legal regulations associated with marriage, particularly if they are unsure about the long-term survival of their union. Therefore, cohabitors may not wish for their rights and obligations to be harmonized with those of married couples, since harmonization may in fact be detrimental to them personally.

Second, not only states but the policies themselves can be classified along a spectrum, with policies that equalize cohabitation with marriage at one end and those that privilege marriage at the other. Surprisingly, the only policy dimension in which cohabitors in all countries have been given similar rights to married couples is the right to remain in their deceased partners' rented housing. In most other policy areas, the rights and obligations of non-registered cohabiting couples differ substantially across countries. It is these other policies that produce the spectrum of states. In general, the Nordic countries and the Netherlands have harmonized most rights, while the German-speaking countries continue to privilege marriage. Although some countries have systematized legal regulations for registered partnerships, the registered partnerships also range along the spectrum, with the Netherlands’ registered partnerships being more similar to marriage and France’s Pacs less similar. Thus, our overview clearly shows that states do vary in their approach to cohabitation and marriage. Further research is needed to show whether this variation matters to actual behavior.

\section{The relationship between parents and children}


Just as the state has an interest in regulating the relationship between adult partners, the state also has an interest in regulating the relationship between parents and children. The state is responsible for protecting children's rights, for example the right to be raised in a safe and secure environment, which usually requires that fathers be identified so they can provide child support. Besides protecting children's rights, however, the state must also protect parental rights, such as the right to acknowledge paternity, which establishes the legal relationship between father and child, or the right to custody which allows parents to make decisions about the child's education, health and residence (Melli 2003). In addition, some states regulate naming conventions that stipulate whether fathers can pass down the family name. As with the policies governing cohabiting couples, policies governing fathers' rights can also be placed along a spectrum with those that equalize cohabitation and marriage at one end and those that privilege marriage at the other.

Historically, states have regulated the relationship between parents and children through marriage. Paternity and custody were automatically assumed for married husbands, as stipulated in several countries' civil codes (e.g. the French Civil Code of 1804 and the German Civil Code of 1900). It is interesting to note that in most countries the $19^{\text {th }}$ century, married mothers generally had far fewer rights over their children than married fathers, especially in case of divorce. The shift to granting mothers sole custody after divorce occurred in the second half of the $19^{\text {th }}$ century or even later, when courts began to make decisions "in the best interests of the child" (Melli 2003). During the past several decades, however, concerns about gender equity and psychological ties with fathers have led courts to provide fathers with greater rights after divorce, and joint custody is on the rise again (Melli 2003). The increase 
in fathers' rights after divorce seems to run parallel with the increase in joint custody for fathers in cohabiting unions.

In the past, parents who had a child outside of marriage received far fewer rights to raise, educate, and care for their children, which often discouraged cohabiting couples from remaining unmarried. The state did not distinguish between unmarried mothers who lived with partners and those who did not: they were all considered lone mothers. In addition, lone mothers were often considered to be deviant and outside of societal norms (Laslett et al 1980). In some countries, the state took an active role in monitoring lone mothers. In Germany, for example, a child born outside of marriage was assigned a legal guardian who represented the legal interests of the child, advised the mother, and tried to establish paternity (Buske 2004). The automatic allocation of a legal guardian was only completely abolished in 1998 (Dienel 2002). Legal guardians were also assigned to non-marital children in Austria (until 1989) and Sweden (until 1972) (Kulms 1994; Dopffel 1994). Today in Switzerland, a child welfare advocate is still appointed for all non-marital children in order to establish paternity and supervise the mother.

Up until the 1970s, unmarried fathers were rarely given joint custody, and some countries even barred unmarried fathers from establishing a legal relationship with their child. For example, until 1970 the German Civil Code explicitly stated that unmarried fathers and their children were not related, and until 1998, German fathers had only limited possibilities to acquire sole custody, with joint custody not an option (Meulders-Klein 1990). The situation was similar in England, where a procedure to establish paternity was only introduced in 1987 (Meulders-Klein 1990). In other countries, such as France or Austria, paternity of nonmarital children could be established, but usually with certain requirements, such as an appearance in court or 
witnesses. Other countries, such as Norway and Sweden, actively required that paternity be established for every child born outside of marriage in order to ensure maintenance payments (Meulders-Klein 1990).

The rights of nonmarital fathers towards their children have been extended throughout European countries during the past decades, most notably by introducing joint custody (Meulders-Klein 1990; Barlow et al. 2005; Hamilton 2002; Forder 1993). However, in none of the European countries considered here has the legal status of married and nonmarried fathers been completely harmonized. These differences might provide incentives for fathers to marry the mother of their child around the time of the birth. Here we describe in greater detail: the establishment of paternity, joint custody, and the right to pass on the family name.

The establishment of paternity. In all countries, the paternity of nonmarital children can be established via father's recognition of the child or court ruling. In some countries, such as Germany (Schweppe 2002) and the Netherlands (Reinhartz 2002), mothers are required to provide consent. If a mother refuses, the father must appeal in court to acquire joint custody (Schrama 2008). In Germany, this right to judicial review was established only in 2010, as discussed above. In other countries, such as Spain or Switzerland, mothers are not granted a right of veto and can only contest the veracity of the paternity claim ex post (Graham-Siegenthaler 2002). In Norway and Sweden, the state still takes an active role in the establishment of paternity, as it did in the past (Saldeen 2002; Lødrup 2002), with Social Welfare offices legally responsible for identifying fathers of nonmarital children. In Austria, the Civil Code automatically assumes paternity for co-residential men who had a sexual relationship with the mother 300 to 180 days before the birth. Paternity is then established via father's recognition of the child, or, in case of controversy, by court ruling (Kriegler 2002). 
Joint custody. In some countries, such as Spain, Italy, France and England, fathers automatically acquire joint custody once both parents register the child (Roca 2002; Ceschini 2002), although some countries stipulate specific requirements (Ferrand 2005). In other countries, such as Germany and the Netherlands, a specific, separate application is required for unmarried fathers to attain joint custody, and again this may depend on the mother's consent (Dethloff 2005; Boele-Woelki and Schrama 2005). Note that in the Netherlands, fathers in registered partnerships automatically receive joint custody (Boele-Woelki and Schrama 2005). Finally, in some states, couples must meet further conditions to acquire joint parental custody. In Austria, parents must share a common household (Kriegler 2002), and in Switzerland, parents must contract a formal agreement regarding the allocation of the personal care and financial responsibility for the child; this contract is then evaluated by guardianship authorities who can grant joint custody if they deem it to be in the best interests of the child (Graham-Siegenthaler 2002).

Passing down the family name. Finally, countries vary as to whether unmarried fathers can transfer their family name to their children. In most countries, couples can jointly decide which surname the child receives, especially if paternity has been established or the couple has registered for joint custody. In Austria, a nonmarital child generally receives the mother's surname, but couples can apply to change the child's name to the father's after the father has acknowledged paternity. In Switzerland, however, this is not the case. Nonmarital children receive the mother's last name, and fathers who would like to pass the paternal family name to their children must marry the mother. Le Goff and Ryser (2010) surmise that this is one of the reasons the percent of births outside of marriage has remained relatively low (17\% in 2008: Eurostat 2010), even though the country has relatively high rates of 
premarital cohabitation. In addition, other aspects of Swiss family law discourage childbearing within cohabitation, such as having to negotiate bureaucratic obstacles to establish paternity and joint custody. Thus, Switzerland appears to be a case where state policies influence the decisions to exit cohabitation and enter marriage primarily when children are involved.

To summarize, even though unmarried fathers have successively acquired more rights in the care, education, and naming of their children, the status and rights of married and unmarried cohabiting fathers have not been completely harmonized in any of the European countries considered here. In general across Europe, unmarried fathers must undertake additional procedures to legally recognize their children, although in some cases, especially if the mother objects, paternity can be established by court ruling. Austria is one of the few exceptions where presumption of paternity applies to cohabiting fathers, based on the assumption that women only have sexual relations with co-resident men. Joint custody, on the other hand, is only automatically conferred to both unmarried parents in some countries, and only under the condition that paternity has been established. In other countries, parents have to actively submit an additional application for joint custody even if paternity has been established. Thus, in all countries examined, cohabiting fathers must undertake extra steps to establish paternity and/or apply for joint custody, while married fathers automatically attain both. As a consequence, bureaucratic obstacles may prompt couples with children to marry -the easiest route in most countries.

\section{CONCLUSION}

Our goal in this paper has been to raise awareness about the potential influence that policies may play in union formation, as well as providing an overview of the 
range of policy dimensions that regulate relations between couples and between parents and children. Although we have provided hints that policies may have an effect, our examples have not led to conclusive evidence that policies have led to the increases in cohabitation, or alternatively that states have reacted to the increases by changing policies. In general, we found evidence that certain countries had longstanding approaches that favored marriage, while others tolerated or even supported alternative family forms. These findings suggest that although cohabiting unions may appear to be an "alternative to marriage" according to the prevalence or duration of unions (Heuveline and Timberlake 2004), they may still be very different in terms of legal recognition. Countries exhibit a great deal of variation in their approach to cohabitation on a number of dimensions, but this approach is not necessarily comprehensive or coherent. Thus, the policy landscape differs significantly across countries, as does its relationship to individual behavior.

Clearly further research is needed to provide more concrete evidence for any relationship that might exist. First, more information is needed about the constellation of policies that may impact cohabitation and childbearing within cohabitation, information that would allow investigations into how quantity and coherence influence behavior, as suggested by Kamerman and Kahn (1991). It is important to note that the policy dimensions we outlined do not have equal weight in impacting couples' union decision-making. In fact, some of the dimensions may be relatively minor. Second, policies need to be situated in historical, welfare, regional, and socioeconomic contexts to better understand how state ideology as a whole may influence the diffusion of cohabitation. Although this may seem to preclude comparison across a large number of countries, a careful comparison should be able to analyze major differences between countries without ignoring context-specific effects. 
Finally, more research is needed to determine whether peoples' knowledge of their rights and obligations accords with what is written in the law, or indeed whether the laws matter at all to their decisions (Barlow et al 2005). Surveys and qualitative research that investigates peoples’ knowledge and attitudes towards legal policy would provide important insights into whether policies do indeed make a difference in couples' decisions to cohabit or to marry.

Taken as a whole, this theoretical overview raises important questions about the changing institution of marriage, as well as the increasing "institutionalization” of cohabitation. If laws and regulations are expanded to incorporate cohabitation, what does that imply for the institution of marriage? If states equalize cohabitation and marriage, does that mean cohabitation is an "alternative to marriage?" In addition, our overview raises questions about the role of children within these unions; policies directed towards granting unmarried fathers equal rights may negate the reason for marrying when children are born. Again, policies may be changing the function of marriage, so that marriage is no longer the sole state-sanctioned relationship for raising children. As a result, children may still play an important part in defining a couple’s commitment and influencing decisions to marry, but they may also become increasingly irrelevant to decisions about converting cohabitation into marriage.

Changing policies to accord cohabitors more rights and responsibilities challenges the legal uniqueness of marriage, but it can also fundamentally change the social and economic function of marriage. The state's recognition of cohabitation as an alternative family form has been fundamental to a societal acceptance of the behavior and its increased practice. Needless to say, people will feel less pressure to marry if the legal and financial benefits to marriage dwindle. As a result, the role of marriage in these societies may take on different social meanings, or may be related to 
less tangible benefits such as status or emotional commitment to the relationship. Studies show that although marriage may be postponed throughout different life events, eventually most people marry (Andersson and Philipov 2002), and indeed most people want to marry (Bernhardt 2004). Thus, the expansion of policies to regulate cohabitation may have little impact on marriage in the long-run. Further research in this area will shed more light onto how the function of marriage and cohabitation has changed over time, why cohabitation especially as a setting for childbearing and rearing is increasing so rapidly, but also whether marriage will ever truly disappear. 


\section{References:}

Agency for Public Management and eGovernment (Difi). "Norway.no: Your gateway to the public sector in Norway."

Andersson, Gunnar and Dimiter Philipov. 2002. "Life-table representations of family dynamics in Sweden, Hungary, and 14 other FFS countries: A project of descriptions of demographic behavior." Demographic Research 7:67-144.

Antokolskaia, Masha and Katharina Boele-Woelki. 2002. "Dutch Family Law in the 21st Century: Trend-setting and straggling behind at the same time." Electronic Journal of Comparative Law.

Baizan, Pau, Arnstein Aassve, and Francesco C. Billari. 2004. "The Interrelations Between Cohabitation, Marriage and First Birth in Germany and Sweden " Population and Environment 25:531-561.

Barlow, Anne, Simon Duncan, Grace James, and Alison Park. 2005. Cohabitation, Marriage and the Law: Social change and legal reform in the 21st century. Portland, Oregon: Hart Publishing.

Becker, Michael. 1994. "Schweiz. Ausgewählte Rechtsfragen des schweizerischen Kindschafts- und Unterhaltsrechts nach der Reform von 1972/76." Pp. 47-70 in Kindschaftsrecht im Wandel. Zwölf Länderberichte mit einer vergleichenden Summe, edited by P. Dopffel. Tübingen: J.C.B. Mohr (Paul Siebeck).

Bernhardt, Eva. 2004. "Cohabitation or marriage? Preferred living arrangements in Sweden." Austrian Institute for Family Studies publication.

Blossfeld, Hans-Peter and Johannes Huinink. 1991. "Human capital investments or norms of role transition? How women's schooling and career affect the process of family formation." The American Journal of Sociology 97:143-168.

Boele-Woelki, Katharina and Wendy Schrama. 2005. "Die nichtehelicher Lebensgemeinschaft im niederländischen Recht." Pp. 307-373 in Die Rechtsstellung nichtehelicher Lebensgemeinschaften, Beiträge zum ausländischen und internationalen Privatrecht, edited by J. M. Scherpe and N. Yassari. Tübingen: Mohr Siebeck.

Borrillo, Daniel and Eric Fassin. 2004. "The Pacs, Four Years Later: A beginning or an end?" Pp. 19-25 in Same-sex couple, same-sex partnerships, and homosexual marriages: A focus on cross-national differences, vol. 124, Documents de travail, edited by P. Digoix Marie and Fest: INED.

Bourdieu, Pierre. 1996. "On the family as a realized category." Theory, Culture and Society 13:19-26.

Bracher, M., Santow, G. 1998. "Economic independence and union formation in Sweden." Population Studies 52:275-294.

Bradley, David. 2001. "Regulation of Unmarried Cohabitation in West-European Jurisdictions - Determinants of legal policy." International Journal of Law, Policy and the Family 15:22-50.

Bundesärztekammer. 2006. "(Muster-)Richtlinie zur Durchführung der assistierten Reproduktion." Deutsches Ärzteblatt 103:A 1392-A 1403.

Bundesministerium der Justiz. 2009. "Gemeinsam Leben - Eine Information für Paare, die ohne Ehe oder eingetragene Lebenspartnerschaft zusammenleben." Pp. 1-19.

Buske, Sybille. 2004. Fräulein Mutter und ihr Bastard. Eine Geschichte der Unehelichkeit in Deutschland 1900-1970, Edited by U. Herbert and L. Raphael. Göttingen: Wallstein Verlag. 
Carlson, Marcia, Irwin Garfinkel, Sara McLanahan, Ronald Mincy and Wendell Primus. 2004. "The effects of welfare and child support policies on union formation." Population Research and Policy Review 23:513-542.

Ceschini, Roberta. 2002. "Italy." Pp. 401-436 in Family Law in Europe, edited by C. Hamilton and A. Perry. London/Edinburgh: LexisNexis Butterworths.

Cherlin, Andrew. 2009. The marriage-go-round: The state of marriage and the family in America today. New York: Knopf.

Council of Europe. 1975. "European Convention on the Legal Status of Children born out of Wedlock." vol. CETS No.: 085.

Conseil des Notariats de l’Union Européenne. 2010. "Successions in Europe. Succession law in 27 European countries."

Coontz, Stephanie. 2005. Marriage, A History: From Obedience to Intimacy, or How Love Conquered Marriage. New York: Viking.

De Schutter, Olivier and Kees Waaldijk. 2005. "Major legal consequences of marriage, cohabitation and registered partnership for different-sex and samesex partners in Belgium." Pp. 49-66 in More or less together. Levels of legal consequences of marriage, cohabitation and registered partnership for different-sex and same-sex partners. A comparative study of nine European countries, edited by K. Waaldijk. Paris: Institut National d'Etudes Démographiques.

Dethloff, Nina. 2005. "Nichteheliche Lebensgemeinschaft und Kinder." Pp. 137-162 in Die Rechtsstellung nichtehelicher Lebensgemeinschaften, edited by J. M. Scherpe and N. Yassari. Tübingen: Mohr Siebeck.

Dienel, Christiane. 2002. Familienpolitik. Eine praxisorientierte Gesamtdarstellung der Handlungsfelder und Probleme. Weinheim München: Juventa Verlag.

Dingeldey, Irene. 2001. "European Tax Systems and their Impact on Family Employment Patterns." Journal of Social Policy 30:653-672.

Dopffel, Peter. 1994. "Dänemark, Norwegen und Schweden. Eltern und Kinder im Recht der nordischen Länder." Pp. 71-118 in Kindschaftsrecht im Wandel. Zwölf Länderstudien mit einer vergleichenden Summe, Studien zum ausländischen und internationalen Privatrecht, edited by P. Dopffel. Tübingen: J.C.B. Mohr (Paul Siebeck) Tübingen.

Ehmer, Josef. 2002. "Marriage." Pp. 282-321 in Family Life in the Long Nineteenth Century, 1789-1913, edited by D. I. K. a. M. Barbagli. New Haven: Yale University Press.

Esping-Andersen, Gosta. 1990. The three worlds of welfare capitalism. Princeton, NJ: Princeton University Press.

Eurostat. 2010. "Eurostat database: Proportion of live births outside marriage." Eurostat.

Ferrand, Frédérique. 2005. "Die Rechtsstellung nichtehelicher Lebensgemeinschaften in Frankreich." Pp. 211-247 in Die Rechtsstellung nichtehelicher Lebensgemeinschaften, Beiträge zum ausländischen und internationalen Privatrecht, edited by J. M. Scherpe and N. Yassari. Tübingen: Mohr Siebeck.

Forder, Caroline. 1993. "Constitutional Principle and the Establishment of the Legal Relationship between the Child and the Non-Marital Father: A study of Germany, the Netherlands and England." International Journal of Law and the Family 7:40-107.

Freiburghaus-Arquint, Dieter. 2000. "Cohabitation non maritale: Etat de la question en droit suisse." Pp. 109-125 in Cohabitation non maritale. Evolution récente en droit suisse et étranger Actes du Colloque de Lausanne du 23 février 2000, 
edited by F. Guilllaume and R. Arn. Geneva: Librairie Droz.

Gauthier, Anne. 2007. "The impact of family policies on fertility in industrialized countries: a review of the literature." Population Research and Policy Review 26:323-346.

Gauthier, Anne Helene. 1996. The State and the Family: A comparative analysis of family policies in industrialized countries. Oxford: Clarendon Press.

Godard, Joëlle. 2007. "Pacs seven years on: Is it moving towards marriage?" International Journal of Law, Policy and the Family 21:310-321.

Goldstein, Josh R. and Sebastian Kluesener. 2009. "Historical Origins of the EastWest Demographic Divide in Germany." in Persistence of the Past. Rostock, Germany.

González Beilfuss, Cristina. 2005. "Spanien und Portugal." Pp. 249-275 in Die Rechtsstellung nichtehelicher Lebensgemeinschaften, Beiträge zum ausländischen und internationalen Privatrecht, edited by J. M. Scherpe and N. Yassari. Tübingen: Mohr Siebeck.

Graham-Siegenthaler, Barbara. 2002. "Switzerland." Pp. 661-701 in Family Law in Europe, edited by C. Hamilton and A. Perry. London/Edinburgh: LexisNexis Butterworths.

Hamilton, Carolyn. 2002. "England \& Wales." Pp. 95-161 in Family Law in Europe, edited by C. Hamilton and A. Perry. London Edinburgh: LexisNexis Butterworths.

Hamilton, Carolyn and Alison Perry. 2002. Family Law in Europe. London/Edinburgh: LexisNexis Butterworths.

Hantrais, Linda. 2004. Family Policy Matters. Responding to family change in Europe. Bristol: The Policy Press.

Hantrais, Linda and Marie-Therese Letablier. 1998. Families and Family Policies in Europe. New York: Longman.

Heuveline, Patrick, and Jeffrey M. Timberlake. 2004. "The role of cohabitation in family formation: the United States in comparative perspective." Journal of Marriage and the Family 66:1214-1230.

Hoem, Jan. 1991. "To Marry, Just in Case ...: the Swedish Widow's-Pension Reform and the Peak in Marriages in December 1989." Acta Sociologica 34:127-135.

—. 2008. "Overview Chapter 8: The impact of public policies on European fertility." Demographic Research 19:249-60.

Hoem, Jan M., Jasilioniene, Aiva, Kostova, Dora, and Muresan, Cornelia. 2009. "Traces of the Second Demographic Transition in selected countries in Central and Eastern Europe: union formation as a demographic manifestation." European Journal of Population 25:123-156.

Kamerman, Sheila and Alfred Kahn. 1991. Child Care, Parental Leave, and the Under 3s: Policy Innovation in Europe. New York: Auburn House.

Kiernan, Kathleen. 2004. "Unmarried Cohabitation and Parenthood: Here to Stay? European Perspectives." in The Future of the Family, edited by D. P. Moynihan, Timothy M. Smeeding, and Lee Rainwater. New York: Russell Sage Foundation.

Knijn, Trudie, Claude Martin, and Jane Millar. 2007. "Activation as a Framework for Social Policies towards Lone Parents." Social Policy and Administration 41:638-652.

Konietzka, Dirk and Michaela Kreyenfeld. 2002. "Women's Employment and NonMarital Childbearing: A Comparison between East and West Germany in the 1990s." Population -E 57:331-358. 
Köppen, Katja. 2009. "Marriage and Cohabitation in Western Germany and France." in Draft of Dissertation. Rostock: University of Rostock.

Kostova, Dora. 2008. "Union formation in times of social and economic change: evidence from the Bulgarian and Russian GGS." Pp. 258 Rostock: Universität Rostock, Wirtschafts- und Sozialwissenschaftliche Fakultät.

Kriegler, Alfred. 2002. "Austria." Pp. 1-32 in Family Law in Europe, edited by C. Hamilton and A. Perry. London/Edinburgh: LexisNexis Butterworths.

Kulms, Rainer. 1994. "Österreich. Ausgewählte Probleme aus dem österreichischen Obsorge- und Unterhaltsrecht." Pp. 9-45 in Kindschaftsrecht im Wandel. Zwölf Länderberichte mit einer vergleichenden Summe, edited by P. Dopffel. Tübingen: J.C.B. Mohr (Paul Siebeck).

Laslett, Peter, Karla Oosterveen, and Richard M. Smith. 1980. Bastardy and its comparative history: Studies in the history of illegitimacy and marital noncomformism in Britain, France, Germany, Sweden, the United States, Jamaica, and Japan London: Edward Arnold.

Le Goff, Jean-Marie. 2002. "Cohabiting unions in France and West Germany: Transitions to first birth and first marriage." Demographic Research 7:593624.

Le Goff, Jean-Marie and Valérie-Anne Ryser. 2010. "The Meaning of Marriage for Men during their Transition to Fatherhood: The Swiss context." Marriage \& Family Review 46:107-125.

Lesthaeghe, Ron. 2010. "The Unfolding Story of the Second Demographic Transition." Population and Development Review 36:211-251.

Liefbroer, Aart C. and Martine Corijn. 1999. "Who, What, Where, and When? Specifying the impact of educational attainment and labor force participation on family formation." European Journal of Population 15:45-75.

Lødrup, Peter. 2002. "Norway." Pp. 493-519 in Family Law in Europe, edited by C. Hamilton and A. Perry. London/Edinburgh: LexisNexis Butterworths.

Mairhuber, Ingrid. 2003. "The Austrian Pension Systems. Forba Research Report 2/2003." Working Life Research Center, Vienna.

Martin, Claude and Irène Théry. 2001. "The Pacs and Marriage and Cohabitation in France." International Journal of Law, Policy and the Family 15:135-158.

Martiny, Dieter. 2005. "Rechtsprobleme der nichtehelichen Lebensgemeinschaft während ihres Bestehens nach deutschem Recht." Pp. 79-99 in Die Rechtsstellung nichtehelicher Lebensgemeinschaften, Beiträge zum ausländischen und internationalen Privatrecht, edited by J. M. Scherpe and N. Yassari. Tübingen: Mohr Siebeck.

McDonald, Peter. 2006. "Low Fertility and the State: The Efficacy of Policy." Population and Development Review 32:485-510.

Melli, Marygold S. 2003. "Child Custody." Pp. 237-242 in International Encyclopedia of Marriage and Family vol. Volume 1, edited by J. J. Ponzetti. New York/Farmington Hills: Macmillan Reference USA.

Meulders-Klein, Marie-Therese. 1990. "The Position of the Father in European Legislation." International Journal of Law and the Family 4:131-153.

Ministry of Health and Social Affairs and National Social Insurance Board. 2007. "The Swedish National Pension System." Pp. 1-25.

Mitterauer, Michael. 1983. Ledige Mütter. Zur Geschichte illegitimer Geburten in Europa. München: Beck.

Neyer, Gerda and Gunnar Andersson. 2008. "Consequences of Family Policies on Childbearing Behavior: Effects or artifacts?" Population and Development 
Review 34:699-724.

Noack, Turid. 2001. "Cohabitation in Norway: An accepted and gradually more regulated way of living." International Journal of Law, Policy and the Family 15:102-117.

O'Donoghue, Cathal and Holly Sutherland. 1998. "Accounting for the Family: The treatment of marriage and children in European income tax systems." UNICEF, Florence.

Ohlsson, Sofi. 2009. "Marriage in Fashion? Trend reversal in marriage formation in Sweden." in Stockholm Research Reports in Demography. Stockholm: Stockholm University.

Oppenheimer, Valerie K. . 2003. "Cohabiting and Marriage during Young Men's Career-Development Process." Demography 40:127-149.

Orloff, Ann Shola. 1993. "Gender and the social rights of citizenship: The comparative analysis of gender relations and welfare states." American Sociological Review 58:303-328.

Ostner, Ilona. 2001. "Cohabitation in Germany - Rules, Reality and Public Discourses." International Journal of Law, Policy and the Family 15:88-101.

Perelli-Harris, Brienna and Theodore P. Gerber. 2011. "Nonmarital childbearing in Russia: Second Demographic Transition or Pattern of Disadvantage?" Demography.

Perelli-Harris, Brienna, Wendy Sigle-Rushton, Trude Lappegård, Renske Keizer, Caroline Berghammer, Michaela Kreyenfeld. 2010a. "The educational gradient of nonmarital childbearing in Europe." Population and Development Review 36:775-801.

Perelli-Harris, Brienna, Wendy Sigle-Rushton, Trude Lappegård, Aiva Jasilioniene, Paola Di Giulio, Renske Keizer, Katja Koeppen, Caroline Berghammer, and Michaela Kreyenfeld. 2010b. "Examining nonmarital childbearing in Europe: How does union context differ across countries?" MPIDR Working Paper WP 2009-021:1-42.

Poortman, Anne-Rigt. 2010. "Legal arrangements in marriage and cohabitation in the Netherlands." in Population Association of America Meeting. Dallas, TX.

Prioux, France. 1993. "The Ups and Downs of Marriage in Austria." Population: An English Selection 5:153-182.

Prskawetz, Alexia, Sobotka Tomáš, Isabella Buber, Henriette Engelhardt, and Richard Gisser. 2008. "Austria: Persistent low fertility since the mid-1980s." Demographic Research 19:293-360.

Reher, David Sven. 1998. "Family ties in Western Europe: Persistent contrasts." Population and Development Review 24:203-234.

Reinhartz, B. E. 2002. "The Netherlands." Pp. 437-467 in Family Law in Europe, edited by C. Hamilton and A. Perry. London/Edinburgh: LexisNexis Butterworths.

Roca, Encarna. 2002. "Spain." Pp. 587-618 in Family Law in Europe, edited by C. Hamilton and A. Perry. London/Edinburgh: LexisNexis Butterworths.

Ryrstedt, Eva. 2005a. "Legal Status of Cohabitants in Norway." Pp. 439-454 in Die Rechtsstellung nichtehelicher Lebensgemeinschaften, Beiträge zum ausländischen und internationalen Privatrecht, edited by J. M. Scherpe and N. Yassari. Tübingen: Mohr Siebeck.

—. 2005b. "Legal Status of Cohabitants in Sweden." Pp. 415-437 in Die Rechtsstellung nichtehelicher Lebensgemeinschaften, Beiträge zum ausländischen und internationalen Privatrecht, edited by J. M. Scherpe and N. 
Yassari. Tübingen: Mohr Siebeck.

Saldeen, Åke. 2002. "Sweden." Pp. 619-660 in Family Law in Europe, edited by C. Hamilton and A. Perry. London/Edinburgh: LexisNexis Butterworths.

Salles, Anne. 2006. "The Effects of Family Policy in the Former GDR on Nuptiality and Births Outside Marriage." Population (english edition) 61:131-142.

Schrama, Wendy. 2008. "Family function over family form in the law on parentage? The legal position of children born in informal relationships." Utrecht Law Review 4:83-98.

Schweppe, Katja. 2002. "Germany." Pp. 291-324 in Family Law in Europe, edited by C. Hamilton and A. Perry. London/Edinburgh: LexisNexis Butterworths.

Statistisches Bundesamt. 2010. "Bevölkerung und Erwerbstätigkeit. Natürliche Bevölkerungsbewegung." vol. Fachserie 1 Reihe 1.1. Wiesbaden.

Sueddeutsche Zeitung. 03.12.2009. "Urteil zum Sorgerecht. Bundesregierung erwägt gesetzliche Änderungen."

Thornton, Arland. 1991. "Influence of the marital history of parents on the marital and cohabitational experiences of children." American Journal of Sociology 96:868-894.

Thornton, Arland, William G. Axinn, and Jay D. Teachman. 1995. "The influence of school enrollment and accumulation on cohabitation and marriage in early adulthood." American Sociological Review 60:762-774.

Trost, Jan 1978. "A Renewed Social Institution: Non-Marital Cohabitation " Acta Sociologica 21:303-315

van de Kaa, Dirk. 2001. "Postmodern fertility preferences: From changing value orientation to new behavior." Global fertility transition. Supplement to Population and Development Review 27:290-338.

Waaldijk, Kees. 2005a. "Major legal consequences of marriage, cohabitation and registered partnership for different-sex and same-sex partners in the Netherlands." Pp. 137-154 in More or less together: Levels of legal consequences of marriage, cohabitation and registered partnership for different-sex and same-sex partners. A comparative study of nine European countries, edited by K. Waaldijk. Paris: Institut National d'Etudes Démographiques.

—. 2005b. More or Less Together: Levels of legal consequences of marriage, cohabitation and registered partnership for different-sex and same-sex partners. A comparative study of nine European countries. Paris.

Wellenhofer, Marina. 2005. "Rechtsprobleme bei Auflösung der nichtehelichen Lebensgemeinschaften - unter Lebenden und im Todesfall." Pp. 101-136 in Die Rechtsstellung nichtehelicher Lebensgemeinschaften, Beiträge zum ausländischen und internationalen Privatrecht, edited by J. M. Scherpe and N. Yassari. Tübingen: Mohr Siebeck.

Xie, Yu, James M. Raymo, Kimberly Goyette, and Arland Thornton. 2003.

"Economic potiential and entry into marriage and cohabitation." Demography 40:351-367.

Ytterberg, Hans and Kees Waaldijk. 2005. "Major legal consequences of marriage, cohabitation and registered partnership for different-sex and same-sex partners in Sweden." Pp. 169-186 in More or less together: Levels of legal consequences of marriage, cohabitation and registered partnership for different-sex and same-sex partners. A comparative study of nine European countries, edited by K. Waaldijk. Paris: Institut National d'Etudes Démographiques. 
Figure 1. Percent of all births born to cohabitation, by country, 1970-latest date available.

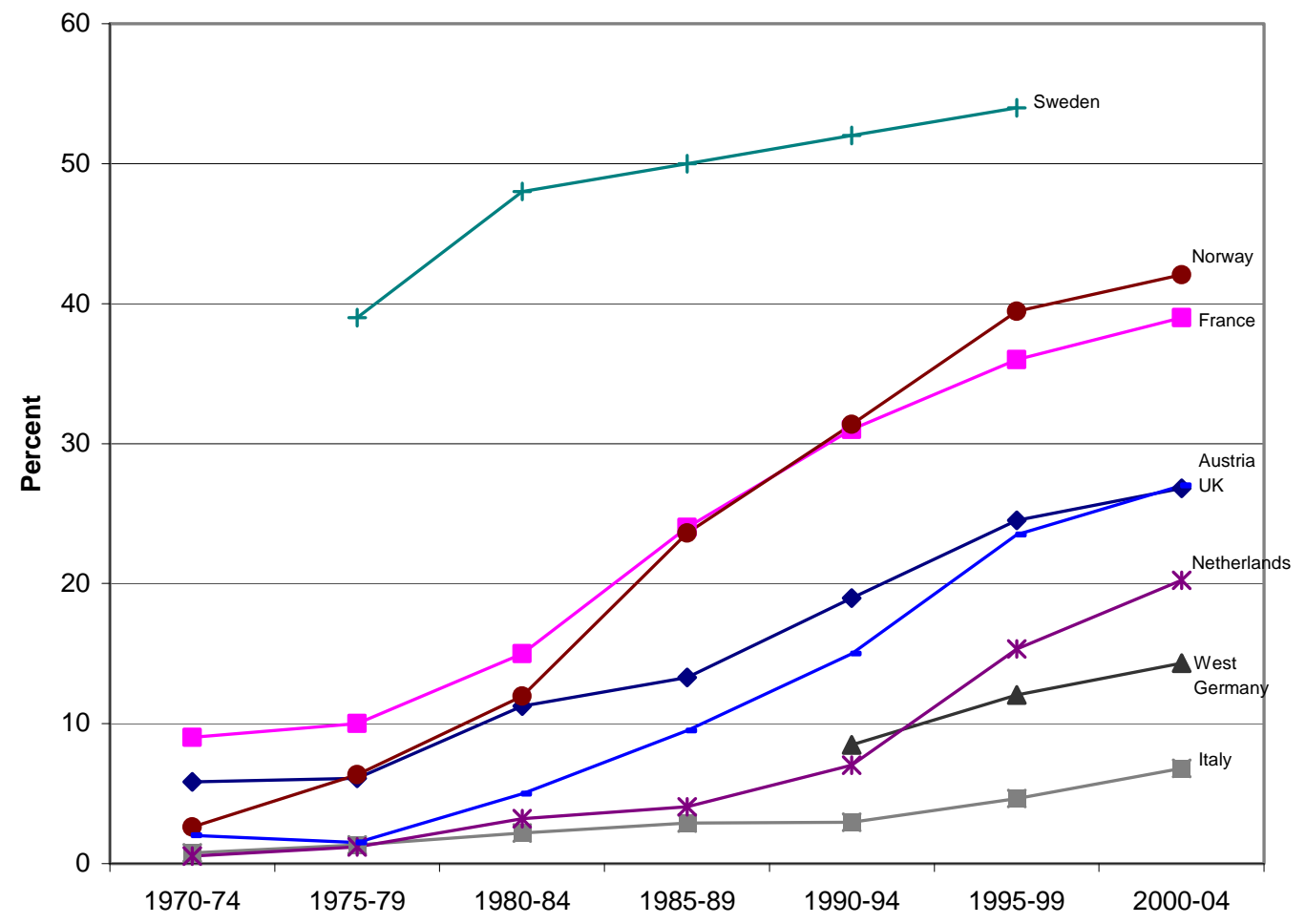

Source: Generations and Gender Surveys in Norway (data provided by Trude Lappegard, Statistics Norway), France (data calculated by Brienna Perelli-Harris, Austria (data provided by Caroline Berghammer, Vienna Institute of Demography), Germany (data provided by Michaela Kreyenfeld, Max Planck Institute of Demography), and Italy (data provided by Paola di Giulio, Vienna Institute of Demography). The British Household Panel Survey (data provided by Wendy Sigle-Rushton, London School of Economics). The Dutch Fertility and Family Survey (data provided by Renske Keizer, Erasmus University Rotterndam), the Swedish Level of Living Standards Survey (Elizabeth Thomson, Stockholm University and Sheela Kennedy, University of Minnesota). 